\title{
The Metabolism of Proinsulin and Insulin by the Liver
}

\author{
A. H. Rubenstein, L. A. Pottenger, M. Mako, \\ G. S. GetZ, and D. F. STEINER \\ From the Departments of Medicine, Pathology, and Biochemistry, \\ University of Chicago, Pritzker School of Medicine, \\ Chicago, Illinois 60637
}

A B STRACT The removal of bovine proinsulin by the isolated perfused rat liver has been studied and the results compared with the removal of insulin. At high concentrations of insulin $(>180 \mathrm{ng} / \mathrm{ml})$ the removal process was saturated and the $t^{\frac{1}{2}}$ varied between 35 and $56 \mathrm{~min}$. With low initial insulin levels the disappearance followed first-order kinetics, the mean regression coefficient being $-0.022, \mathrm{t}^{\frac{1}{2}} 13.8 \mathrm{~min}$, and the hepatic extraction $4.0 \mathrm{ml} / \mathrm{min}$. The results with proinsulin were in striking contrast to these findings. At both high and low concentrations the hepatic removal of proinsulin was considerably slower, averaging 10-15 times less than that of insulin. Specific immunoassay techniques and gel filtration of samples taken from perfusions to which both labeled and unlabeled proinsulin had been added did not show conversion to either insulin or the $\mathrm{C}$-peptide.

Bovine and rat ${ }^{181}$ I-labeled proinsulins were degraded more slowly than bovine insulin ${ }^{131} \mathrm{I}$ by bovine and rat liver homogenates. Both proinsulin and insulin inhibited the degradation of insulin- ${ }^{12} \mathrm{I}$, equimolar quantities of proinsulin being 2-5 times less effective than insulin.

These results indicate significant differences in the capacity of the liver to remove and degrade insulin and proinsulin. The low hepatic extraction of proinsulin may account for its prolonged half-life in vivo and contribute to its relatively high plasma concentration in the fasting state. Furthermore this finding will have to be taken into account in the interpretation of changes in the proinsulin: insulin ratios in peripheral blood in a variety of metabolic situations.

\section{INTRODUCTION}

Proinsulin, the single-chain polypeptide precursor of insulin, has been identified in human $(1-6)$, bovine $(7,8)$,

Received for publication 21 July 1971 and in revised form 18 Novernber 1971. and porcine plasma (9). Its concentration in the fasting state $(3,10)$ and change in response to a variety of stimuli such as glucose $(3)$, tolbutamide $(4,11,12)$, and arginine (4) have been measured. These results have suggested that the relationship of proinsulin to the concomitant plasma insulin level may have physiological significance, and a great deal of emphasis has thus been placed upon alterations in the plasma proinsulin: insulin ratio (13). In previously reported studies, differential rates of secretion of these two polypeptides by the pancreatic beta cells have been considered the main determinants of their blood concentrations. It is obvious, however, that the existence of significant differences in the peripheral distribution and metabolism of proinsulin and insulin may also influence their absolute blood levels and ratio. Since the liver is the major organ that removes insulin from the circulation (14), we examined the hepatic extraction of proinsulin by the isolated perfused rat liver and compared the results with those obtained with insulin. In addition, the degradation of these two hormones by rat and bovine liver homogenates has been studied.

\section{METHODS}

Liver perfusion (15). Livers (12.5-15.0 g) from nonfasted, chow-fed Sprague-Dawley rats weighing 325-400 g were perfused in situ in an apparatus similar to that described by Mortimore, Tietze, and Stetten (16). The perfusate $(80-90 \mathrm{ml})$ consisted of heparinized blond from fed rats with the hematocrit adjusted to $20 \%$ by addition of Krebs-Ringer bicarbonate buffer ( $\mathrm{pH} 7.4)$ containing 4 $\mathrm{g} / 100 \mathrm{ml}$ bovine serum albumin (Armour Fraction V, Armour Pharmaceutical Co., Kankakee, Ill.) and $200 \mathrm{mg} /$ $100 \mathrm{ml}$ glucose. The flow rate was adjusted to $23-25 \mathrm{ml} /$ $\min (1.5-2.0 \mathrm{ml} / \mathrm{g}$ per $\mathrm{min})$. In each experiment care was taken to ensure that the liver retained its normal red-brown appearance and did not become swollen. Biopsy specimens of six livers showed no histological changes. The common bile duct was cannulated and the bile production measured. The flow ranged between 0.8 and $1.2 \mathrm{ml} / \mathrm{hr}$, which is similar to previous reports (17). The enzyme glutamic-pyruvic 
transaminase was assayed (18) in the initial and final perfusate sample from each experiment. The values were below $10 \mathrm{IU}$ and did not increase significantly in the latter samples. 20-30 min after the commencement of the perfusion a control perfusate sample was taken, and insulin or proinsulin was added to the reservoir. Thereafter samples (approximately $1.0 \mathrm{ml}$ ) were removed at 5 - to $10-\mathrm{min}$ intervals, so that less than $12 \%$ of the perfusate volume was taken during any particular experiment. The rate of disappearance of the added proinsulin or insulin was followed for $60 \mathrm{~min}$ in 18 experiments and for $2-3 \mathrm{hr}$ in an additional 8 experiments. In four instances proinsulin- ${ }^{181} \mathrm{I}$ or insulin- ${ }^{131} \mathrm{I}$ was perfused for $120 \mathrm{~min}$.

The results were calculated both in terms of the absolute concentration of insulin and proinsulin and as a percentage of the initial concentration determined $5 \mathrm{~min}$ after addition of the hormone to the perfusate when mixing had occurred. The concentration of endogenous insulin in the perfusate was below $5.0 \mu \mathrm{U} / \mathrm{ml}$ immediately before the addition of the hormone, and amounted to less than $2 \%$ of the lowest initial concentration of exogenous insulin measured in the perfusate at $5 \mathrm{~min}$. Subtraction of this value from the later samples did not significantly influence the results. The regression coefficients were calculated by the method of least squares from linear portions of the graph obtained by semilogarithmic plots of the data. The hepatic clearances of proinsulin and insulin (in milliliters per minute) were calculated according to Mortimore et al. (16), and Burgi, Kopetz, Schwarz, and Froesch (19) as $k=2.3 V / \Delta t$ $\log \left(\left[C_{1}-C_{\alpha}\right] /\left[C_{2}-C_{\alpha}\right]\right)$ where $k=$ hepatic clearance or reaction velocity constant, $V=$ volume of perfusion fluid, $C_{1}$ and $C_{2}=$ initial and final concentrations over the time interval $\Delta t$, and $C_{\alpha}=$ asymptote approached by $C$ after prolonged perfusion. Preliminary experiments with low concentrations of the two hormones indicated their disappearance from the medium $(<0.5 \mathrm{ng} / \mathrm{ml})$ after prolonged perfusion (3-4 hr) and thus $C_{\alpha}$ was taken as zero. Using this value, the half-life was determined in the following equation : $t \frac{1}{2}=\log 2 \times 2.3 \times V / k$ (19).

Liver homogenates (20). Chow-fed, male Sprague-Dawley rats (200-250 g) were killed by stunning and decapitation. Their livers were rapidly removed, cooled to $4^{\circ} \mathrm{C}$, and cut into small pieces which were gently blotted to remove as much blood as possible. In addition, pieces of bovine liver (approximately $20 \mathrm{~g}$ ) were obtained at the slaughterhouse and transferred to the laboratory at $4^{\circ} \mathrm{C}$ with a delay of 20-30 min. Approximately $1.0 \mathrm{~g}$ of tissue was weighed and homogenized in phosphate buffer $(0.1 \mathrm{M})$ containing $5 \times 10^{-3} \mathrm{M}$ disodium ethylenediaminetetraacetate (EDTA), $\mathrm{pH} 7.4$, at $4^{\circ} \mathrm{C}$. The homogenate was adjusted to $8 \% \mathrm{w} / \mathrm{v}$ and centrifuged at $2400 \mathrm{rpm}(1450 \mathrm{~g})$ for 30 $\min$ at $4^{\circ} \mathrm{C}$. The substrate consisted of insulin or proinsulin labeled with ${ }^{131} \mathrm{I}$ in phosphate buffer $(0.1 \mathrm{M}, \mathrm{pH} 7.4)$ containing $10^{-2} \mathrm{M}$ mercaptoethanol, $1.0 \mathrm{~g} / 100 \mathrm{ml}$ bovine serum albumin, and $10^{-3} \mathrm{M}$ EDTA. The concentration of the labeled substrate was $1.0-2.0 \mathrm{ng} / \mathrm{ml}$ and varying concentrations of cold insulin and proinsulin were added as indicated.

$1 \mathrm{ml}$ portions of the homogenate supernatant were pipetted into chilled tubes, followed by $1.0 \mathrm{ml}$ of substrate. Immediately, $2.0 \mathrm{ml}$ cold $10 \%$ trichloroacetic acid (TCA) was added to control tubes and the remainder were mixed and transferred to a $37^{\circ} \mathrm{C}$ water bath for periods of time varying from 2.5 to $60 \mathrm{~min}$. At the end of each time interval $2 \mathrm{ml} 10 \%$ TCA was added to the appropriate tubes, which were removed from the water bath and thoroughly mixed.
The tubes were centrifuged at $2000 \mathrm{rpm}$ for $30 \mathrm{~min}$ and the supernate decanted. The precipitate was washed with an additional $2.0 \mathrm{ml} 10 \% \mathrm{TCA}$, recentrifuged, and counted in a Packard autogamma Spectrometer (Packard Instrument Co., Inc., Downers Grove, Ill.).

The nonincubated control tubes contained the maximum of TCA-precipitable ${ }^{131} \mathrm{I}$ and represented $100 \%$ of the substrate available for degradation. The TCA-precipitable ${ }^{131} \mathrm{I}$ in the other tubes was proportional to the undegraded substrate and the percentage degraded was calculated as 100 $-(\mathrm{cpm}$ in experimental tube $) /(\mathrm{cpm}$ in control tube $) \times 100$.

Immunoassay. Insulin and proinsulin were measured in duplicate by a modification (3) of the double antibody immunoassay of Morgan and Lazarow (21). Because the bovine proinsulin antiserum cross-reacted weakly with insulin (22) certain samples were also assayed with a purified preparation of this antiserum, from which the insulin-binding antibodies had been removed by passage over a Sepharose-insulin complex (23).

Standards. Bovine proinsulin and insulin were purified from first crystals of insulin (kindly supplied by the Novo Company, Copenhagen, Denmark) (24). Immunoassay of fractions after gel filtration showed less than $0.3 \%$ contamination of proinsulin with material eluting in the insulin region of the column, while the insulin was essentially free of early eluting components. Material for the liver perfusion and homogenate experiments, immunoassay standards, and radioactive labeling was taken from the same batches of purified insulin and proinsulin. The rat proinsulin was prepared by Dr. J. Clark (25).

Radioactively labeled proteins. Bovine insulin and bovine and porcine proinsulin were labeled with carrier-free ${ }^{131} \mathrm{I}$ (750-1000 $\mathrm{mCi} / \mathrm{ml}$; Union Carbide Corp., New York) by the method of Hunter and Greenwood (26) to specific activities of $20-50 \mathrm{mCi} / \mathrm{mg}$. The labeled hormones were checked as follows: ( $a$ ) by gel filtration on columns of Biogel P-30 equilibrated in $3 \mathrm{~m}$ acetic acid (more than $96 \%$ of the radioactivity was recovered in the expected elution volume of the column); (b) by binding to their specific antisera (more than $97 \%$ of either was bound by an excess of insulin or proinsulin antiserum); and $(c)$ by trichloroacetic acid precipitability (more than $98 \%$ was precipitated). In addition, the ${ }^{181}$ I-labeled proinsulin was quantitatively converted to material behaving like insulin on gel chromatography after incubation with trypsin $(1 \mu \mathrm{g} / \mathrm{ml})$ (22). The labeled hormones were used within 5-7 days after iodination to prevent artifacts due to varying degrees of "damage" that invariably could be detected during the 2nd to 3rd wk of storage of these preparations.

Gel filtration. Standards and radioactively labeled insulin and proinsulin as well as samples from the liver perfusion were gel filtered on $1 \times 50 \mathrm{~cm}$ columns of Biogel P-30 equilibrated in $3 \mathrm{~m}$ acetic acid as previously described ( 3 , 27). Perfusate samples $(0.1 \mathrm{ml})$ with high concentrations of proinsulin or insulin were mixed with $0.9 \mathrm{ml} 3 \mathrm{M}$ acetic acid and applied directly to the columns. Perfusates containing low concentrations of hormone were extracted and concentrated by a modification of the Davoren procedure $(3,28)$ before gel filtration. After evaporation to dryness, the column fractions were taken up in the immunoassay buffer.

Statistical procedures. These were performed according to methods described by Snedecor and Cochran (29). 


\section{RESULTS}

Liver perfusion. Preliminary experiments with initial insulin concentrations of $80-150 \mathrm{ng} / \mathrm{ml}$ showed an alteration in the disappearance curve of the hormone during the course of the $60 \mathrm{~min}$ perfusion. We considered the possibility that insulin was being degraded nonspecifically by the accumulation of proteolytic enzymes or other substances in the perfusion medium. However, perfusate removed at the end of the experiment did not degrade added ${ }^{131} \mathrm{I}$-labeled insulin or immunoreactive insulin during an additional $30-60 \mathrm{~min}$ incubation at $37^{\circ} \mathrm{C}$. The problems was resolved by raising or lowering the initial insulin concentration. With 5min insulin values of $150-220 \mathrm{ng} / \mathrm{ml}$, the disappearance of insulin followed the pattern of zero-order kinetics during the 1-hr perfusion, while with initial concentrations of $10-20 \mathrm{ng} / \mathrm{ml}$ the insulin disappearance was first order. Similar concentrations of proinsulin were then used in parallel experiments so that a direct comparison of the hepatic extraction of the two hormones could be made.

The results with high initial insulin concentrations $(184-215 \mathrm{ng} / \mathrm{ml})$ are shown in Fig. 1. The time taken for the perfused insulin level to fall to $50 \%$ of the 5 min value was $35-56 \mathrm{~min}$ (mean, $49 \mathrm{~min}$ ). At low concentrations $(11.2-14.6 \mathrm{ng} / \mathrm{ml})$, insulin disappeared at a considerably faster rate, the mean regression coefficient of insulin disappearance in the four experiments being -0.0220 , $\mathrm{t}^{\frac{1}{2}} 13.8 \mathrm{~min}$, and the hepatic ex-

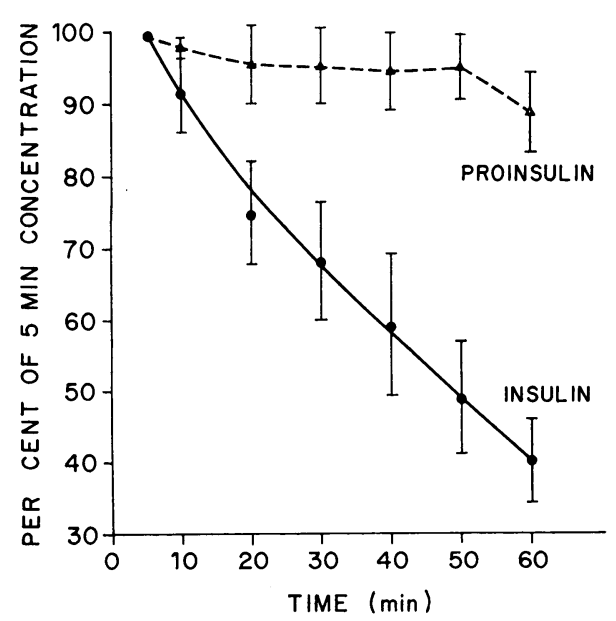

FigURE 1 Disappearance curves of high concentrations of insulin and proinsulin in the isolated perfused rat liver. The concentrations $5 \mathrm{~min}$ after the addition of the hormones were $168-215 \mathrm{ng} / \mathrm{ml}$ and the results are expressed as a percentage of these levels. Each point represents the mean $\pm S D$ of five experimental values. The proinsulin and insulin percentages from 10 to $60 \mathrm{~min}$ differed significantly from each other $(P<0.05)$. The regression equation for insulin between 20 and $60 \mathrm{~min}$ was $y=-0.887+93.94$. traction $4.0 \mathrm{ml} / \mathrm{min}$ (Table $\mathrm{I}$ ). When the mean values at each individual time period were used to calculate the regression coefficient, half-time, or hepatic clearance, essentially similar results were obtained.

The data for proinsulin are shown in Table I and Fig. 1. In contrast to insulin, proinsulin was removed extremely slowly at both high (Fig. 1) and low (Table I) concentrations. The perfusate taken at $60 \mathrm{~min}$ contained more than $70 \%$ of the 5 min level in all experiments, whereas the corresponding insulin level was less than $50 \%$ at high and $10 \%$ at low concentrations. The proinsulin concentrations in some samples were slightly higher than those obtained at earlier times. These samples were reassayed at various dilutions on a number of occasions with similar results. Although this observation might be explained by outward diffusion of proinsulin which had been temporarily sequestered in the liver, detailed further studies will be needed to provide an unequivocal answer.

In order to further explore the reasons for the different half-disappearance times for insulin at various concentrations, four livers were perfused for longer periods of time $(120-150 \mathrm{~min})$. The initial disappearance curves for the experiments with 5 min levels of 136, 245, and $520 \mathrm{ng} / \mathrm{ml}$ were relatively slow (Fig. 2), being comparable to the results shown in Fig. 1. However, a change in the removal rate occurred in each experiment (at 45, 75, and $105 \mathrm{~min}$ ) when the perfusate concentration had reached 64, 54, and 104 $\mathrm{ng} / \mathrm{ml}$ respectively. Thereafter the regression coefficients were $-0.02214,-0.02025$, and -0.01811 which were similar to the value observed in the fourth perfusion with a $5 \mathrm{~min}$ insulin concentration of 13.6 $\mathrm{ng} / \mathrm{ml}$ and in the low concentration perfusions (Table I, 1-4). In parallel experiments the disappearance of proinsulin was followed for $180 \mathrm{~min}$. The initial concentrations were $328,144,16.8$, and $3.8 \mathrm{ng} / \mathrm{ml}$ and declined gradually to reach $50 \%$ of these levels in $2-3$ hr.

Because the antiserum used to assay proinsulin in these experiments cross-reacted with insulin and the isolated C-peptide, it was possible that conversion of proinsulin to these two products might have contributed to the immunoreactive "proinsulin" levels observed. Therefore 10 samples were reassayed after removal of the insulin-reactive antibodies from the antiserum (Fig. 3 ). The concentrations measured with the adsorbed antiserum were not consistently lower than those obtained initially and there was no significant difference between the mean values in the two assay systems.

Further studies were performed using gel filtration to ascertain whether conversion of proinsulin occurred. Medium from perfusions in which insulin ${ }^{131} \mathrm{I}$ or proinsulin- ${ }^{121} \mathrm{I}$ had been added was taken after 30 and $60 \mathrm{~min}$

914 A. H. Rubenstein, L. A. Pottenger, M. Mako, G. S. Getz, and D. F. Steiner 
TABLE I

Removal of Bovine Insulin and Proinsulin by the Isolated Perfused Rat Liver

\begin{tabular}{|c|c|c|c|c|c|c|c|c|c|c|}
\hline \multirow{3}{*}{$\begin{array}{l}\text { Per- } \\
\text { fusion } \\
\text { No. }\end{array}$} & \multicolumn{7}{|c|}{ Time $(\min )$} & \multirow{3}{*}{$\begin{array}{c}\text { Regression } \\
\text { coefficient } \\
\text { (mean } \pm \mathrm{Sb}) *\end{array}$} & \multirow{3}{*}{$\begin{array}{c}\text { Extrac- } \\
\text { tion }\end{array}$} & \multirow{3}{*}{$\begin{array}{l}\text { Half-dis- } \\
\text { appearance } \\
\text { time } t \frac{1}{2}\end{array}$} \\
\hline & 5 & 10 & 20 & 30 & 40 & 50 & \multirow[t]{2}{*}{60} & & & \\
\hline & Conc. & \multicolumn{5}{|c|}{ Per cent of 5 min concentration } & & & & \\
\hline & $n g / m l$ & & & & & & & & $\mathrm{ml} / \mathrm{min}$ & $(\min )$ \\
\hline \multicolumn{11}{|c|}{ (a) Insulin (low concentration) } \\
\hline 1 & 14.6 & 80.0 & 55.9 & 27.6 & 18.5 & 12.0 & 7.4 & $-20.847 \pm 1.039$ & 3.8 & 14.4 \\
\hline 2 & 13.7 & 60.2 & 35.3 & 17.6 & 11.8 & 6.8 & 4.5 & $-24.044 \pm 3.097$ & 4.4 & 12.5 \\
\hline 3 & 12.8 & 85.5 & 44.6 & 28.2 & 15.9 & 10.0 & 6.8 & $-21.945 \pm 0.967$ & 4.0 & 13.7 \\
\hline 4 & 11.2 & 78.3 & 40.1 & 24.3 & 17.6 & 10.0 & 7.2 & $-20.966 \pm 2.081$ & 3.9 & 14.4 \\
\hline Mean & 13.1 & 76.0 & 44.0 & 24.4 & 16.0 & 9.7 & 6.5 & $-21.800 \pm 0.835$ & 4.0 & 13.8 \\
\hline SD & 1.3 & 9.5 & 7.6 & 4.2 & 2.6 & 1.9 & 1.2 & & & \\
\hline \multicolumn{11}{|c|}{ (b) Proinsulin (low concentration) } \\
\hline 5 & 18.2 & 96.2 & 96.1 & 97.0 & 94.4 & 91.0 & 87.6 & $-0.858 \pm 0.071$ & 0.16 & 350.9 \\
\hline 6 & 17.0 & 95.3 & 96.0 & 93.0 & 89.2 & 89.7 & 73.7 & $-1.826 \pm 0.555$ & 0.38 & 146.9 \\
\hline 7 & 16.5 & 93.0 & 92.9 & 76.8 & - & 72.4 & 71.9 & $-2.701 \pm 0.544$ & 0.50 & 111.5 \\
\hline 8 & 12.8 & 92.1 & 91.9 & 89.2 & 88.1 & 80.6 & 80.0 & $-1.581 \pm 0.133$ & 0.29 & 190.4 \\
\hline Mean & 16.1 & $94.2 \ddagger$ & $94.2 \S$ & $89.0 \S$ & $90.6 \S$ & $83.4 \S$ & $78.3 \S$ & $-1.657 \pm 0.146 \S$ & $0.31 \S$ & $181.7 \S$ \\
\hline SD & 2.0 & 1.7 & 1.9 & 7.5 & 2.8 & 7.5 & 6.2 & & & \\
\hline
\end{tabular}

$* 10^{3} \times$ mean $\pm \mathrm{Sb}, \log$ insulin (or proinsulin) $: t$.

$\ddagger P=<0.02$ compared with corresponding insulin value.

$\S P=<0.001$ compared with corresponding insulin value.

and gel filtered on Biogel P-30 columns. The radioactivity eluted in its expected position and no evidence for conversion of proinsulin to insulin was observed (Fig. 4). Samples taken from the nonradioactive perfusions showed a single peak of immunoreactivity in the proinsulin region of the column when measured

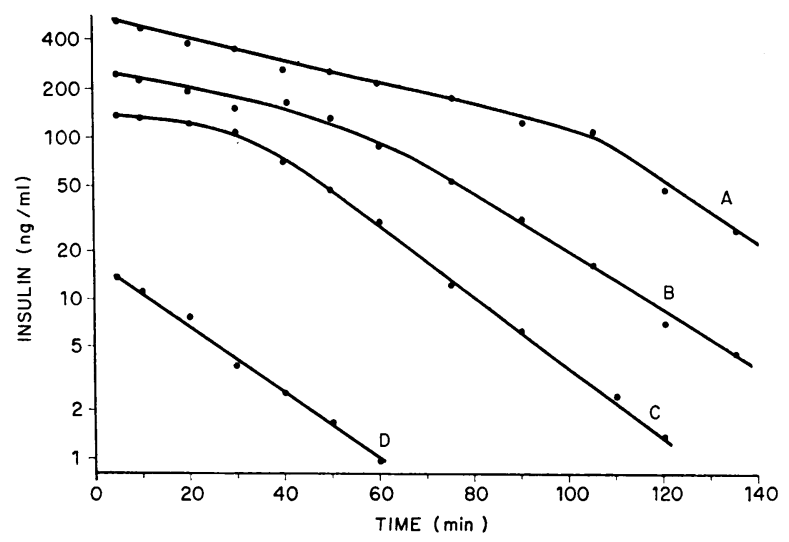

FIGURE 2 Disappearance curves of insulin during prolonged perfusions in the isolated rat liver. The initial disappearance curves for perfusions $\mathrm{B}, \mathrm{C}$, and $\mathrm{D}$ with high initial insulin concentrations were slow. After 45, 75, and 105 $\min$ the regression lines were $-0.02214,-0.02025$, and -0.01811 , while that of $\mathrm{D}$ was -0.02090 . with either the adsorbed or cross-reacting proinsulin antiserum (Fig. 5). Assay of the fractions with an insulin antiserum confirmed these findings (Fig. 5). The presence of either insulin or free C-peptide derived by proteolytic cleavage of proinsulin would have been de-

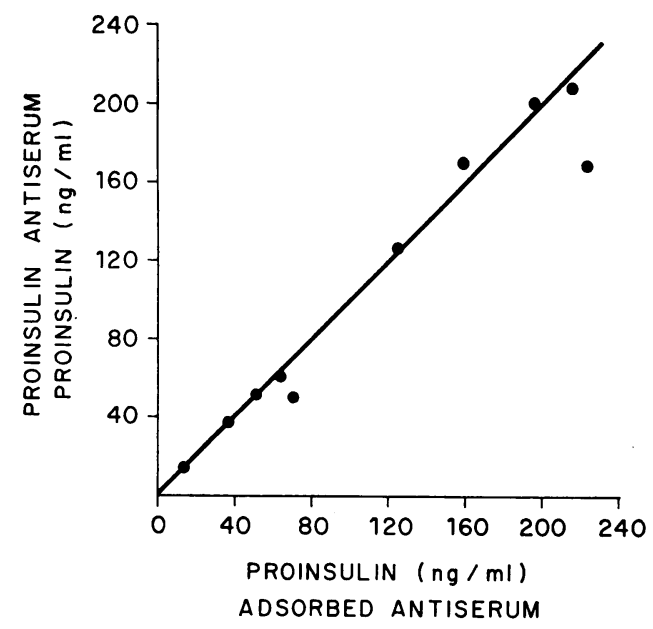

Figure 3 Assay of perfusate samples with two proinsulin antisera. The ordinate represents the values obtained using a proinsulin antiserum which cross-reacts with insulin, while the values on the abscissa were obtained with an antiserum from which the insulin-binding antibodies had been removed. 


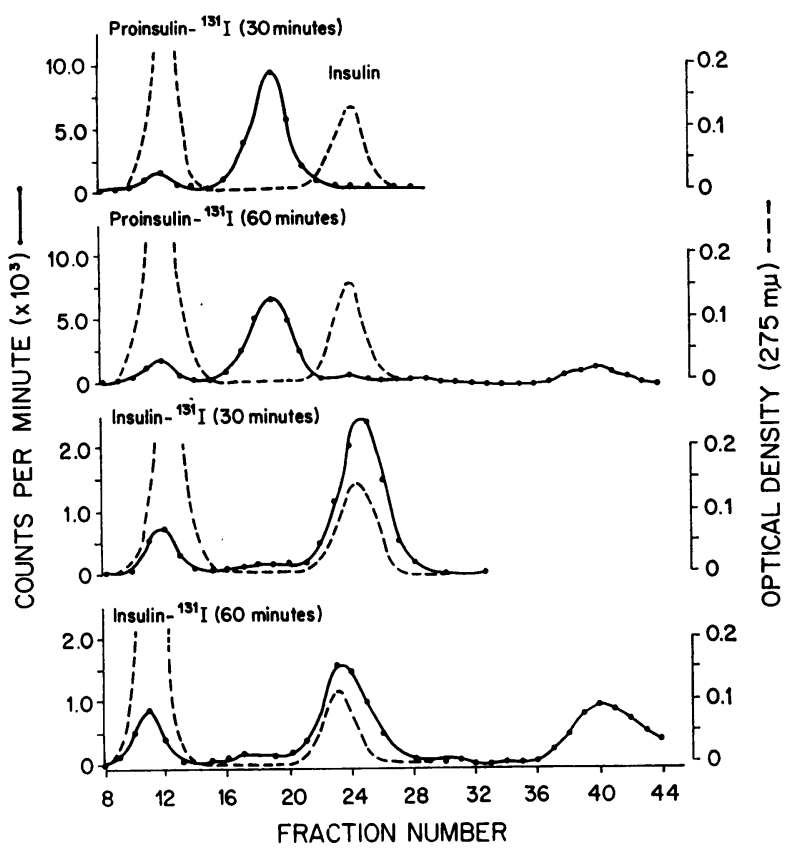

FIGURE 4 Gel filtration patterns of 30 - and 60-min samples taken from perfusions to which insulin- ${ }^{181} \mathrm{I}$ and proinsulin${ }^{131} \mathrm{I}$ had been added. The insulin peak on the column was marked by adding $1.0 \mathrm{mg}$ bovine insulin to each sample before application to the column. Only 32 fractions were collected for the 30 -min samples, while 44 were obtained for the $60-\mathrm{min}$ samples. The recovery of total radioactivity applied to the column was 92 and $94 \%$ for the $60-\mathrm{min}$ proinsulin and insulin samples respectively. The percentage distribution of radioactivity ( $60 \mathrm{~min}$ proinsulin) was 14 (void volume), 72 (proinsulin peak), and 13 (iodide peak); while that for insulin ( $60 \mathrm{~min}$ ) was 16 (void volume), 48 (insulin peak), and 36 (iodide peak). Control experiments in which proinsulin- ${ }^{181} \mathrm{I}$ and insulin- ${ }^{181} \mathrm{I}$ were gel filtered after incubating for $30-60 \mathrm{~min}$ at $37^{\circ} \mathrm{C}$ in perfusate medium showed that more than $94 \%$ of the radioactivity eluted in the insulin or proinsulin fractions.

tected by this combination of immunoassays. Essentially similar results were obtained after gel filtration of acid-ethanol extracts of samples containing low proinsulin concentrations.

Liver homogenates. The increase in trichloroacetic acid-soluble radioactivity during incubation of insulin${ }^{181}$ I with $8 \%$ rat liver homogenates is shown in Table II. Addition of increasing quantities of bovine insulin resulted in progressive inhibition of the reaction, so that only $6 \%$ of the labeled hormone was degraded at $60 \mathrm{~min}$ in the presence of $100 \mu \mathrm{g} / \mathrm{ml}\left(16 \times 10^{-8} \mathrm{M}\right)$. Equilmolar amounts of proinsulin were less inhibitory than insulin, so that at 10 min proinsulin exerted only 56,35 , and $33 \%$ of the inhibitory effects of insulin at concentrations of $1.6,3.2$, and $16 \times 10^{-6} \mathrm{M}$. Proinsulin${ }^{181}$ I was converted to TCA-soluble products approximately 5 times more slowly than insulin $(7.1 \%$ com- pared with $33.2 \%$ at $10 \mathrm{~min}$ ), while the degree of inhibition of proinsulin ${ }^{-131} \mathrm{I}$ breakdown by $15 \mu \mathrm{g}$ proinsulin was similar to the effect of $100 \mu \mathrm{g}$ insulin on insulin${ }^{181}$ I degradation (Table II).

Fig. 6 shows the results with labeled bovine insulin and proinsulin, and rat proinsulin. Both species of proinsulin were degraded at a similar rate, which was considerably slower than that of insulin. Because we did not have sufficient rat proinsulin for inhibition studies, bovine proinsulin was used. At a concentration of 50 $\mu \mathrm{g} / \mathrm{ml}$, almost complete inhibition of the degradation of ${ }^{131}$ I-labeled rat and bovine proinsulin occurred.

The results of experiments using bovine liver homogenates were essentially similar. Bovine ${ }^{181}$ I-labeled proinsulin was degraded more slowly than bovine ${ }^{181}$ I-labeled insulin (10\% compared with $53 \%$ after $10 \mathrm{~min}$ incubation). Furthermore, whereas $100 \mu \mathrm{g}$ insulin decreased the degradation of insulin- ${ }^{131} \mathrm{I}$ at $10 \mathrm{~min}$ from 38.6 to

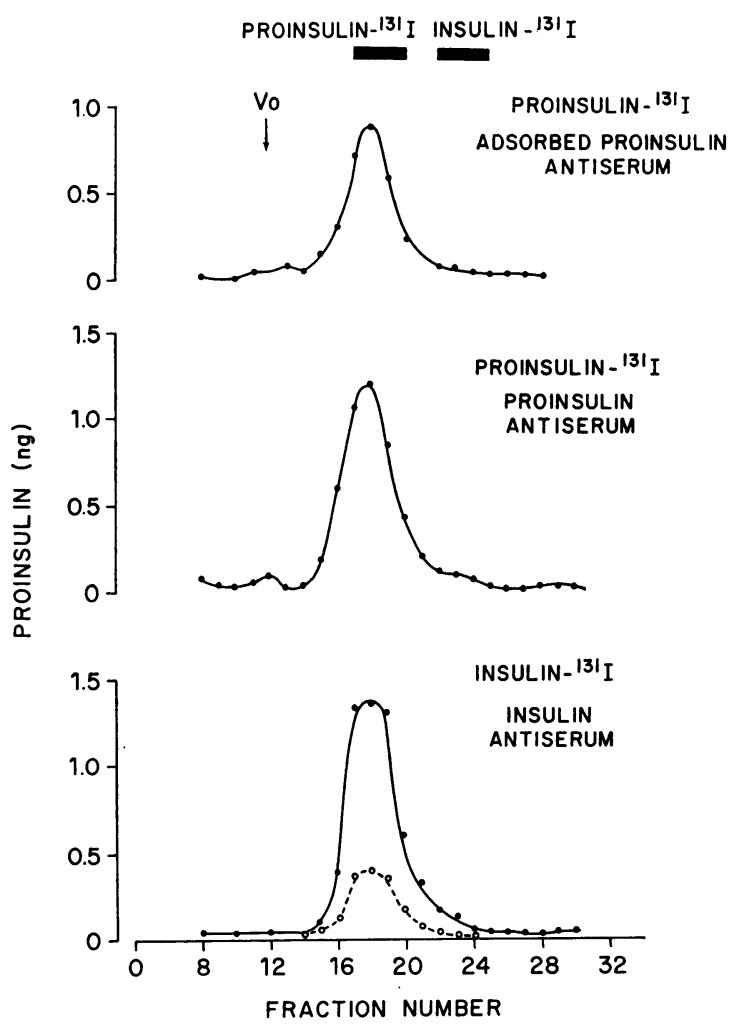

Figure 5 Gel filtration of a sample taken $2 \mathrm{hr}$ after the addition of proinsulin to the isolated liver perfusion medium. The column was calibrated with insulin- ${ }^{131} \mathrm{I}$ and proinsulin${ }^{131} \mathrm{I}$. Portions were measured in three assay systems: top panel $(0.4 \mathrm{ml})=$ adsorbed proinsulin antiserum, proinsulin${ }^{131} \mathrm{I}$, proinsulin standard; middle panel $(0.5 \mathrm{ml})=$ proinsulin antiserum, proinsulin- $I^{\text {san }}$, proinsulin standard; lower panel $(0.5 \mathrm{ml})=0-0$ insulin antiserum, insulin $-^{181} \mathrm{I}$, proinsulin standard; $0--O$ insulin antiserum, insulin- ${ }^{181} \mathrm{I}$, insulin standard. 
TABLE II

Degradation of Proinsulin-131 I and Insulin- ${ }^{131}$ I by $8 \%$ Homogenate of Rat Liver

\begin{tabular}{|c|c|c|c|c|c|c|c|c|c|c|c|}
\hline \multirow[b]{3}{*}{ Substrate } & \multicolumn{11}{|c|}{ Time $(\min )$} \\
\hline & 0 & 2.5 & 5 & 7.5 & 10 & 15 & 20 & 30 & 40 & 50 & 60 \\
\hline & \multicolumn{11}{|c|}{ Per cent trichloroacetic acid-soluble radioactivity } \\
\hline Insulin-131I & 0 & 11.1 & 23.3 & 30.4 & 33.2 & 39.1 & 42.5 & 45.0 & 45.8 & 48.3 & 50.1 \\
\hline$+10 \mu \mathrm{g}$ insulin & 0 & 2.1 & 9.7 & - & 14.1 & 15.7 & 20.4 & 26.3 & 30.2 & 33.3 & 36.6 \\
\hline$+15 \mu \mathrm{g}$ proinsulin & 0 & 7.6 & 14.8 & 17.9 & 25.2 & 31.3 & 34.4 & 37.9 & 42.0 & 42.4 & 44.9 \\
\hline$+20 \mu \mathrm{g}$ insulin & 0 & 1.1 & 2.2 & 4.2 & 5.3 & 10.6 & 12.2 & 14.6 & 18.8 & 23.4 & 24.4 \\
\hline$+30 \mu \mathrm{g}$ proinsulin & 0 & 6.0 & 11.1 & - & 16.8 & 23.5 & 27.4 & 33.8 & 37.8 & 38.0 & 40.9 \\
\hline$+100 \mu \mathrm{g}$ insulin & 0 & 0.3 & - & 0.7 & 1.3 & 2.8 & 2.9 & 5.8 & 6.6 & 7.3 & 9.0 \\
\hline$+150 \mu \mathrm{g}$ proinsulin & 0 & - & 3.3 & 3.8 & 6.2 & 10.5 & 12.2 & 16.9 & 18.0 & 21.4 & 23.7 \\
\hline Proinsulin-131I & 0 & - & 3.7 & 6.1 & 7.1 & 10.5 & 12.1 & 14.4 & 15.0 & 15.8 & 15.8 \\
\hline$+15 \mu \mathrm{g}$ proinsulin & 0 & - & 1.0 & - & 1.4 & - & 4.2 & 4.0 & 5.4 & 7.2 & 8.6 \\
\hline
\end{tabular}

$5.7 \%$, an equimolar concentration of proinsulin inhibited the reaction much less $(38.6-27.7 \%)$ (Fig. 7).

\section{DISCUSSION}

The liver has long been considered the most important organ for removal of insulin from the circulation (3032). Since all endogenously secreted insulin must pass through the liver before reaching peripheral tissues, the degree of hepatic extraction of insulin can markedly influence systemic insulin levels $(31,32)$. A major problem in quantitating this effect in vivo has been the difficulty in accurately measuring the total hepatic blood flow (32). Nevertheless, there is general agreement that a substantial amount of portal vein insulin is taken up by the liver in a single transhepatic passage. Kaplan and Madison (33) estimated that $54 \%$ of insulin injected intraportally was extracted by the liver during a single passage, while Samols and Ryder (30) found that the mean hepatic insulin retention in the fasting state was $41 \%$. As yet similar studies with proinsulin have not been published, but it is obvious that posthepatic blood levels and ratios of insulin and proinsulin will be markedly affected by the relative handling of the two polypeptides by the liver.

In contrast to the complexities of the in vivo situation, the isolated perfused rat liver has proven to be a useful system for studying the hepatic uptake of various proteins and polypeptides. Mortimore et al. (16), using insulin ${ }^{131} \mathrm{I}$ as a tracer, found that $40 \%$ of the insulin presented to the liver was removed in a single passage and that the hepatic extraction was approximately $3.0 \mathrm{ml} / \mathrm{min}$. Solomon, Fenster, Ensinck, and Williams (34) obtained comparable results using an isolated fat cell bioassay to measure the disappearance of porcine insulin, while Burgi et al. (19) found a hepatic clearance of $2.67 \mathrm{ml} / \mathrm{min}$ and half-disappearance time of $42 \mathrm{~min}$ for unlabeled rat insulin assayed by the rat epididymal fat pad method. In recent studies with this system, Marshall, Gingerrich, and Wright (35) have monitored the hepatic extraction of porcine insulin by a sensitive and specific immunoassay.

Although it would be useful to compare the absolute values obtained by other investigators with those obtained in the present study, differences in volume and composition of perfusate, hepatic flow, liver size, and

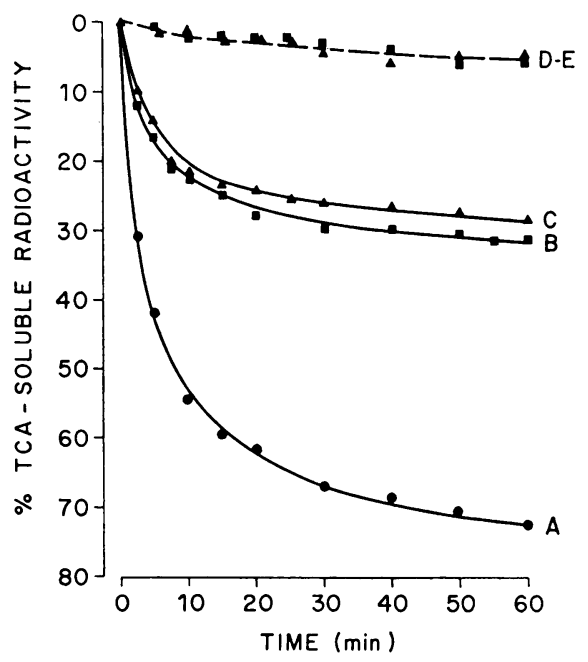

FIGURE 6 Degradation of bovine insulin- ${ }^{181}$ I (A), proinsu$\operatorname{lin}^{-{ }^{131} I}(\mathrm{~B})$, and rat proinsulin-181 I (C) by rat liver homogenates. The inhibition of rat (D) and bovine (E) proinsulin${ }^{131}$ I degradation by $50 \mu \mathrm{g}$ bovine proinsulin is shown. 


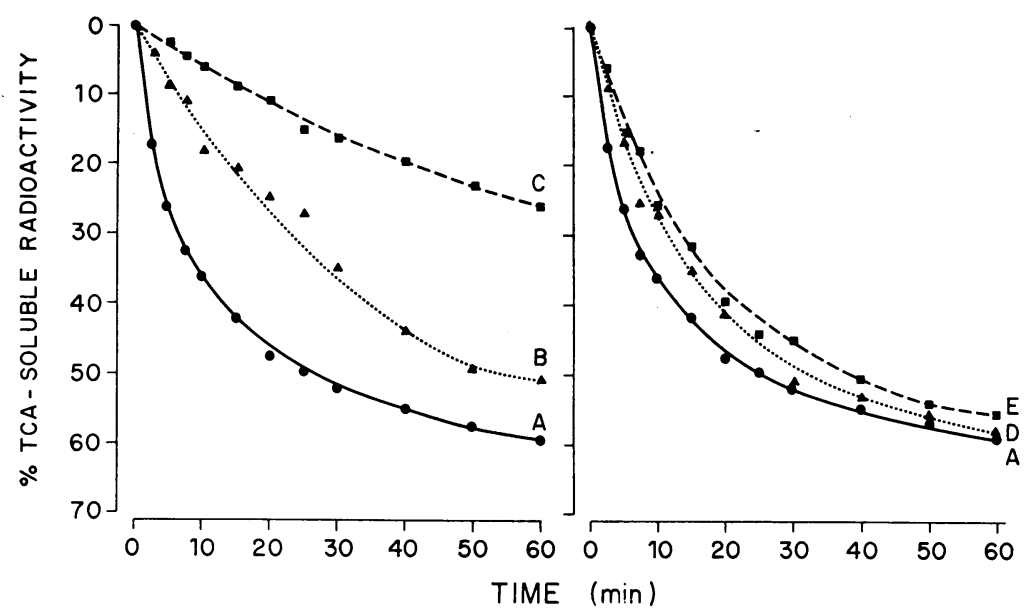

Figure 7 Degradation of bovine insulin- ${ }^{131} \mathrm{I}$ by bovine liver homogenates. (A) insulin ${ }^{131} \mathrm{I}$, (B) insulin- ${ }^{131} \mathrm{I}+20 \mu \mathrm{g}$ insulin, (C) insulin- ${ }^{131} \mathrm{I}+100 \mu \mathrm{g}$ insulin, (D) insulin- ${ }^{-131} \mathrm{I}+30 \mu \mathrm{g}$ proinsulin, (E) insulin- ${ }^{131} \mathrm{I}+150 \mu \mathrm{g}$ proinsulin.

assay technique render such comparisons difficult. Nevertheless, the results obtained with initial insulin concentrations between 10 and $20 \mathrm{ng} / \mathrm{ml}(250-500 \mu \mathrm{U} /$ ml) (Table I), which is within the reported range for portal vein insulin levels in man (36), are almost identical with those of Buchanan, Solomon, Vance, Porter, and Williams (37) and Solomon et al. (34). In addition, the rates for hepatic insulin extraction, which minimize methodological differences to a large extent, are similar to previously reported values $(16,19,34$, 37). It is of interest that the rate of insulin removal slowed appreciably at perfusate concentrations greater than $80 \mathrm{ng} / \mathrm{ml}(2000 \mu \mathrm{U} / \mathrm{ml})$ (Fig. 1). This change implies saturation of one of the components in the uptake or degradative process, but as yet we have no information as to the rate-limiting step. The findings of Hoffenberg, Gordon, Black, and Louis (38) with albumin clearance contrast with these results and suggest that these processes may be relatively specific for each protein. Furthermore, Arnould, Ooms, and Franckson (39) have shown that the reabsorption and destruction of insulin by the dog kidney is not saturable even at extremely high hormone concentrations, indicating that the metabolism of insulin may differ significantly in various organs.

The hepatic extraction of proinsulin was considerably slower than insulin at both high and low concentrations. The mean values for regression coefficients and hepatic extractions were approximately 10-15 times less than those for insulin. With prolonged perfusions the fall in proinsulin concentration was more obvious, but the most rapid half-disappearance time was still longer than $100 \mathrm{~min}$. Stoll, Touber, Menahan, and Williams (40) described similar results with porcine proinsulin and the C-peptide, the mean value after $60 \mathrm{~min}$ perfusion being similar to the initial concentration. The possible contribution of degradation or conversion products, particularly insulin and C-peptide, to the immunoassayable "proinsulin" levels was excluded by measuring perfusate samples with the adsorbed antiserum and by gel filtration of selected samples. It must be realized, however, that neither technique definitively excludes the conversion of intact single-chain proinsulin to its two-chain intermediate forms. In this regard, Lazarus, Gutman, and Recant (41) have separated proinsulin from its intermediates by polyacrylamide disc gel electrophoresis and further studies using this method are planned. Nevertheless, the present results do not support the hypothesis that proinsulin may be fully transformed to insulin and C-peptide by the liver (42) with subsequent liberation of these products into the posthepatic circulation.

Brush (43) has purified a sulfhydryl-dependent proteolytic enzyme from rat skeletal muscle which degraded insulin 33 times faster than proinsulin. This author, as well as others $(43,44)$, has shown that rat liver also contains insulin-degrading activity, and that the purified enzyme does not cleave proinsulin $(45,46)$. The present study has demonstrated that crude rat or bovine liver homogenates destroy radioactively labeled insulin appreciably faster than proinsulin. Because of the many differences in amino acid composition and sequence in the connecting peptide regions of proinsulin from various species $(47,48)$, we considered the possibility that the slow cleavage of bovine proinsulin by rat liver homogenates may depend, at least in part, upon the use of a heterologous polypeptide in these experiments. However, comparable results were obtained with la- 
beled rat and bovine proinsulin in both rat and bovine liver homogenate preparations. Proinsulin acted as a competitive inhibitor of insulin degradation indicating the presence of substantial structural similarities in the two molecules. This finding is in accord with biological (49) and physical data (50) and complements the results of Brush (43) using the rat muscle enzyme and Challoner (51) with isolated adipose cells. Although these findings provide one possible mechanism for the differences in hepatic insulin and proinsulin metabolism, other processes such as membrane binding or pinocytosis may also be involved (38). In this regard the studies of Freychet, Roth, and Neville (52) on the binding of insulin $-{ }^{131} \mathrm{I}$ to liver membranes has indicated the feasibility of comparative studies in this area.

If the marked differences in the handling of proinsulin and insulin by the isolated perfused rat liver are representative of the in vivo situation, then the relative concentrations of these hormones in the systemic circulation must be interpreted in this light. The halflife of proinsulin injected into peripheral veins of monkeys, pigs (53), or dogs (54) is 15-20 min, which is more than twice that of insulin. Preliminary studies have shown that the arteriovenous concentration difference of insulin and proinsulin across the kidney, which is the other major organ for removal of these hormones from the systemic circulation, is similar (54). Thus it is probable that the lower hepatic extraction of proinsulin not only permits a greater proportion of proinsulin secreted by the beta cells to reach the peripheral circulation, but plays an important part in prolonging its systemic half-life. The results of Stoll et al. (53), indicating that pharmacological doses of injected proinsulin have a more prolonged hypoglycemic effect than insulin, are in keeping with these observations. Furthermore, the preliminary data of Rees and Madison (55), which showed that proinsulin is equipotent with insulin in terms of hepatic biological activity, indicate that hepatocellular degradative and metabolic sites may not be closely linked.

In normal weight and obese nondiabetic subjects a relatively high proinsulin: insulin ratio is present in the fasting state and $2-5 \mathrm{hr}$ after an oral glucose load (3, 4). The absolute levels of both hormones rise 30-60 min after glucose, the increase in insulin being of greater magnitude. Thereafter the insulin concentration falls more rapidly than proinsulin. Although these observations could be explained by differential secretory rates of proinsulin and insulin by pancreatic beta cells, the present findings suggest an alternative explanation. Nonetheless, it is obvious that these two possibilities are not exclusive and may indeed coexist. The problem is further complicated by the findings of Marshall, Gingerrich, and Wright (56) that the hepatic removal of insulin is altered by the nutritional status of the animal. Whether the extraction of proinsulin is similarly affected is not known. In any event, it is clear that extensive additional studies will be needed to satisfactorily answer this question. In particular the secretory rates of proinsulin and insulin should be measured in isolated pancreas or islet preparations, portal vein levels and ratios should be compared with posthepatic values, and the in vivo and in vitro hepatic extraction of the two polypeptides should be assessed simultaneously at various plasma concentrations and under a variety of metabolic conditions.

\section{ACKNOWLEDGMENTS}

We wish to thank Dr. J. Miller of the Department of Pathology for the glutamic-pyruvic transaminase determinations.

This study was supported by grants AM 13941, AM 13914, HE 12332 of the U. S. Public Health Service and an award from the Schweppe Foundation, Chicago.

\section{REFERENCES}

1. Rubenstein, A. H., S. Cho, and D. F. Steiner. 1968. Evidence for proinsulin in human urine and serum. Lancet. 1: 1353.

2. Roth, J., P. Gordon, and I. Pastan. 1968. "Big insulin"; new component of plasma insulin detected by immunoassay. Proc. Nat. Acad. Sci. U.S.A. 61: 138.

3. Melani, F., A. H. Rubenstein, and D. F. Steiner. 1970. Human serum proinsulin. J. Clin. Invest. 49: 497.

4. Gorden, P., and J. Roth. 1970. Plasma insulin: fluctuations in the "Big" insulin component in man after glucose and other stimuli. J. Clin. Invest. 48: 2225.

5. Sherman, B. M., P. Gorden, J. Roth, and P. Freychet. 1971. Circulating insulin: the proinsulin-like properties of "Big" insulin in patients without islet cell tumors. J. Clin. Invest. 50: 849.

6. Goldsmith, S. J., R. S. Yalow, and S. A. Berson. 1969. Significance of human plasma insulin sephadex fractions. Diabetes. 18: 340 .

7. Yip, C. C., and J. Logothetopoulos. 1969. A specific antiproinuslin serum and the presence of proinsulin in calf serum. Proc. Nat. Acad. Sci. U.S.A. 62: 415.

8. Rubenstein, A. H., J. L. Clark, F. Melani, and D. F. Steiner. 1969. Secretion of proinsulin C-peptide by pancreatic $\beta$ cells and its circulation in blood. Nature (London). 224: 697 .

9. Stoll, R. W., J. L. Touber, J. L. Ensinck, and R. H. Williams. 1970. Substances immunologically related to proinsulin or connecting peptide in swine plasma. Horm. Metab. Res. 2: 153.

10. Gorden, P., B. Sherman, and J. Roth. 1970. "Big" insulin (circulating proinsulin-like components): a high proportion of basal insulin. Diabctes. 19(Suppl. 1) : 360 . (Abstr.)

11. Melani, F., W. G. Ryan, A. H. Rubenstein, and D. F. Steiner. 1970. Proinsulin secretion by a pancreatic beta cell adenoma: proinsulin and C-peptide secretion. $N$. Engl. J. Med. 283: 713.

12. Gutman, R. A., N. R. Lazarus, J. C. Penhos, S. Fajans, and L. Recant. 1971. Circulating proinsulin-like material in functioning insulinomas. N. Engl. J. Med. 284: 1003. 
13. Rubenstein, A. H., and D. F. Steiner. 1971. Proinsulin. Annu. Rev. Med. 22: 1.

14. Izzo, J. L., J. W. Bartlett, A. Roncone, M. J. Izzo, and W. F. Bale. 1967. Physiological processes and dynamics in the disposition of small and large doses of biologically active and inactive ${ }^{181} \mathrm{I}$-insulin in the rat. J. Biol. Chem. 242: 2342.

15. Pottenger, L. A., and G. S. Getz. 1971. Serum lipoprotein accumulation in livers of orotic acid fed rats. $J$. Lipid Res. 12 : 450.

16. Mortimore, G. E., F. Tietze, and D. Stetten. 1959. Metabolism of insulin- $\mathrm{I}^{\text {ist }}$ : studies in isolated perfused rat liver and hind limb preparations. Diabetes. 8: 307.

17. Exton, J. H., and C. R. Clark. 1967. Control of gluconeogenesis in the liver. J. Biol. Chem. 242: 2622.

18. Henry, R. J., N. Chiamore, G. W. Orville, and S. Berkman. 1960. Revised spectrophotometric methods for the determination of glutamic-oxalacetic transaminase, glutamicpyruvic transaminase and lactic acid dehydrogenase. Amer. J. Clin. Pathol. 34: 381.

19. Burgi, H., K. Kopetz, K. Schwarz, and E. R. Froesch. 1963. Fate of rat insulin in rat liver perfusion: studied by adipose tissue assay. Lancet. $2: 314$.

20. Morgan, C. R., and H. J. Wiesman. 1968. Liver insulinase activity in insulin deficient rats. Proc. Soc. Exp. Biol. Med. 127: 763.

21. Morgan, C. R., and A. Lazarow. 1963. Immunoassay of insulin: two antibody system. Plasma insulin levels of normal, subdiabetic and diabetic rats. Diabetes. 12: 115.

22. Rubenstein, A. H., D. F. Steiner, S. Cho, A. M. Lawrence, and L. Kirsteins. 1969. Immunological properties of bovine proinsulin and related fractions. Diabetes. 18: 598.

23. Wide, L., and J. Porath. 1966. Radioimmunossay of proteins with the use of Sephadex-coupled antibodies. Biochim. Biophys. Acta. 130: 257.

24. Steiner, D. F., O. Hallund, A. H. Rubenstein, S. Cho, and C. Bayliss. 1968. Isolation and properties of proinsulin, intermediate forms, and other minor components from bovine insulin. Diabetes. 17: 725.

25. Clark, J. L., and D. F. Steiner. 1969. Insulin biosynthesis in the rat: demonstration of two proinsulins. Proc. Nat. Acad. Sci. U.S.A. $62: 278$.

26. Hunter, W. M., and F. C. Greenwood. 1962. Preparation of iodine-labelled human growth hormone of high specific activity. Nature (London). 194: 495.

27. Melani, F., A. H. Rubenstein, P. E. Oyer, and D. F. Steiner. 1970. Identification of proinsulin and C-peptide in human serum by a specific immunoassay. Proc. Nat. Acad. Sci. U.S.A. 67: 148.

28. Davoren, P. R. 1962. The isolation of insulin from a single cat pancreas. Biochim. Biophys. Acta. 63: 150.

29. Snedecor, G. W., and W. G. Cochran. 1967. Statistical Methods. The Iowa State University Press, Ames, Iowa. 6th edition.

30. Samols, E., and J. A. Ryder. 1968. Studies on tissue uptake of insulin in man using a differential immunoassay for endogenous and exogenous insulin. J. Clin. Invest. 47: 1947.

31. Kaneko, R., K. Kosaka, and K. Nakao. 1967. Effect of stimulation of the vagus nerve on insulin secretion. Endocrinology. 80: 530.

32. Kanazawa, Y., T. Kuzuya, T. Ide, and K. Kosaka. 1966. Plasma insulin responses to glucose in femoral, hepatic and pancreatic veins in dogs. Amer. J. Physiol. 211: 442.
33. Kaplan, N., and L. L. Madison. 1959. Effects of endogenous insulin secretion on the magnitude of hepatic binding of labelled insulin during a single transhepatic circulation in human subjects. Clin. Res. 7: 248.

34. Solomon, S. S., L. F. Fenster, J. W. Ensinck, and R. H. Williams. 1967. Clearance studies of insulin and nonsuppressible insulin-like activity (SILA) in the rat liver. Proc. Soc. Exp. Biol. Med. 126: 166.

35. Marshall, A., R. L. Gingerrich, and P. H. Wright. 1970. Hepatic effect of sulfonylureas. Metab. (Clin. Exp.). 19: 1046.

36. Blackard, W. G., and N. C. Nelson. 1970. Portal and peripheral vein immunoreactive insulin concentrations before and after glucose infusion. Diabetes. 19: 302.

37. Buchanan, K. D., S. S. Solomon, J. E. Vance, H. P. Porter, and R. H. Williams. 1968. Glucagon clearance by the isolated perfused rat liver. Proc. Soc. Exp. Biol. Med. 128: 620 .

38. Hoffenberg, R., A. H. Gordon, E. G. Black, and L. N. Louis. 1970. Plasma protein metabolism by the perfused rat liver. Biochem. J. 118: 401.

39. Arnould, Y., H. A. Ooms, and J. R. M. Franckson. 1967. Analysis of urinary excretion of insulin in the normal dog. Arch. Int. Pharmacodyn. Ther. 167: 480.

40. Stoll, R. W., J. L. Touber, L. H. Menahan, and R. H. Williams. 1970. Clearance of porcine insulin, proinsulin, and connecting peptide by the isolated rat liver. Proc. Soc. Exp. Biol. Med. 111: 894.

41. Lazarus, N. R., R. A. Gutman, and L. Recant. 1971. A method for electrophoretic characterization on polyacrilamide gel of circulating insulin immunoreactive substances. Anal. Biochem. 49: 241.

42. Mashiter, K., and T. M. King. 1969. Changes of immunoreactivity of proinsulin induced by rat tissue extracts. Nature (London). 224: 696.

43. Brush, J. S. 1971. Purification and characterization of a protease with specificity for insulin from rat muscle. Diabetes. 20: 140.

44. Tomizawa, H. H., and R. H. Williams. 1955. Studies on the specificity of an insulin-inactivating system of the liver. J. Biol. Chem. 217: 685.

45. Burghen, G. A., J. S. Brush, S. S. Solomon, and A. E. Kitabchi. 1971. Inhibition of liver insulin specific protease by plasma inhibitors. Clin. Res. 19: 81 .

46. Burghen, G. A., J. S. Brush, S. S. Solomon, J. N. Etteldorf, and A. E. Kitabchi. 1971. Inhibition of insulin degradation by extracts of human plasma. Diabetes. 20 (Suppl. 1) : 342. (Abstr.)

47. Chance, R. E., R. M. Ellis, and W. W. Bromer. 1968. Porcine proinsulin: characterization and amino acid sequence. Science (Washington). 161: 165.

48. Steiner, D. F., S. Cho, P. E. Oyer, S. Terris, J. D. Peterson, and A. H. Rubenstein. 1971. Isolation and characterization of proinsulin C-peptide from bovine pancreas. J. Biol. Chem. 246: 1365.

49. Gliemann, J., and H. H. Srenson. 1970. Assay of insulinlike activity by the isolated fat cell method. IV. The biological activity of proinsulin. Diabetologia. 6: 499.

50. Frank, B. H., and A. J. Veros. 1968. Physical studies on proinsulin-association behavior and conformation in solution. Biochem. Biophys. Res. Commun. 32: 276.

51. Challoner, D. R. 1971. Degradation of porcine insulin and proinsulin by rat adipose tissue. Diabetes. $20: 276$. 
52. Freychet, P., J. Roth, and D. M. Neville. 1971. Monoiodoinsulin: demonstration of its biological activity and binding to fat cells and liver membranes. Biochem. Biophys. Res. Commun. 43: 400.

53. Stoll, R. W., J. L. Touber, L. C. Winterscheid, J. W. Ensinck, and R. H. Williams. 1971. Hypoglycemic activity and immunological half-life of porcine insulin and proinsulin in baboons and swine. Endocrinology. 88: 714.
54. Rubenstein, A. H., M. Mako, D. F. Steiner, D. Brown, and T. N. Pullman. 1970. The renal extraction and excretion of proinsulin. J. Lab. Clin. Med. 76: 868.

55. Rees, K. O., and L. L. Madison. 1969. The effect of proinsulin on hepatic glucose output, arterial glucose and free fatty acid concentrations in dogs. Diabetes. 18 (Suppl. 1) : 341. (Abstr.)

56. Marshall, A., R. L. Gingerrich, and P. H. Wright. 1970. Hepatic metabolism of insulin in vivo. Clin. Res. 18: 33. 